\title{
THE INFLUENCE OF MARKET RISKS UPON THE AGRIBUSINESS VALUE
}

\author{
Inna Riepina ${ }^{1}$, Nataliia Chukhraieva ${ }^{2}$, Eckhard Kehrein ${ }^{3}$ \\ ${ }^{1}$ Prof. Dr Kyiv National Economic University Named After Vadym Hetman, Peremoha Ave. 54/1, Kyiv, Ukraine. \\ Phone number+380509276793. E-mail address rephousenew@gmail.com \\ ${ }^{2}$ Assoc. Prof. PhD Kyiv National Economic University Named After Vadym Hetman, Peremoha Ave. 54/1, Kyiv, Ukraine. \\ Phone number +380980719930. E-mail address 0612nataliya@gmail.com \\ ${ }^{3}$ Business consultant, trainer and coach, CEO of Horst Rogush Foundation, Academy of Sunstainable \\ Enterpreneurship, Platz der Republik 6-8, D-42107 Wuppertal, Germany. \\ Phone number+380509276793. E-mail address Eckhard.Kehrein.KUb@t-online.de
}

Received 2507 2019; Accepted 09032020

\begin{abstract}
The activities of agriculture enterprises are those referred to the riskiest types of entrepreneurship, because there exists certain dependence on the risks of production activities and market risks, especially marketing and price risks, each of the above mentioned has its own specific manifestation and impact on the company value in this sector. The aim of the study is to study the origins of the market risks emergence and their impact on the cost of agribusinesses in the new business environment. Farmers do not normally pay attention to market risks and do not analyze the types of products that increase their company value. This problem can be solved by using the $\mathrm{ABC}$-analysis of the agricultural product mix, the "sales as contribution to reimbursement" analysis, the introduction of a restricting system on the use of valuable natural resources and diversification. The use of economic and mathematical methods allows us to find a rational production structure of an agricultural enterprise, to calculate the optimal structure of its crop area or an area of a separate group of agricultural crops.

Key words: Agribusiness, Assessment, Diversification, Entrepreneurship, Market, Risks, Value.

JEL classification: M21, Q12, Q13.
\end{abstract}

\section{Introduction}

Agriculture is one of the crucial components of the economy of any country. It produces food for the population, raw materials for the processing industry, satisfies other needs of the society. The efficiency of this type of economic activity is always a challenging matter, especially in the face of a harsh sales market competition for agricultural products. Market risks that arise during this type of economic activity can significantly affect the efficiency of agribusiness activities (Gontareva, 2011). Therefore, the valuation of market risks becomes the basis for strategic and operational management of successful agribusiness enterprises.

Quite many scholars paid their attention to risk origins at different times. So, for the first time, the idea of risk as a quantitative measure of uncertainty was expressed in the work "Risk, Uncertainty and Income" of the American economist Knight (1921). In turn, representatives of the classical theory of risk Mill (1848) and Senior (1854) considered the risk as a mathematical expectation of losses that may arise as a result of a certain decision. Marshall (1879) was one of the pioneer scientists to consider the problem of the economic risk's emergence, his works were the beginning of the neoclassical theory of risk. Keynes (1936) introduced the concept of "risk aversion" to science, characterizing investment and business risks, one of those economists who introduced the classification of risks. The American scholars Neumann and Morgenstern (1944) introduced further development of the theory of risk, as well as Hungarian economists Bakchai and Mesen (1979).

Copyright (C) 2020. Published by Vytautas Magnus University. This is an open access article distributed under the terms of the Creative Commons Attribution Non-Commercial 4.0 (CC BY-NC 4.0) license, which permits unrestricted use, distribution, and reproduction in any medium provided the original author and source are credited. The material cannot be used for commercial purposes. 
Significant contributions to the development of theory and practice of risk was presented by American economists - Nobel Prize winners Arrow (1965), Markowitz (1959), Sharp (1964) and others. Another direction was related to the development of market risk issues. They are based on the economics and mathematical studies of Bollerslow, Barone-Adese, Engli and Giannopoulos. The research results of the above-mentioned scientists have been widely used in the popular concepts of market risk management (RiskMetrics, CreditMetrics, CorporateMetrics) developed by Zangari, Gupton and Finger. The analysis of works published on the subject matter of the study shows that most scientific sources are devoted to the analysis of individual risk problems (Boiko, 2017; Shoaib, 2019). That is why there is still several unresolved issues related to the development of the concept and methods for managing market risks and assessing their impact on the cost of agribusinesses.

The unpredictability of climatic conditions and changes in harvest volumes, price fluctuations on the domestic and foreign markets are the key factors affecting the capitalization of incomes of agribusinesses and the change in their value (Lakis, 2013). Market risks are manifested as the probability of losses or additional opportunities as a result of changes in the economic situation in the market or in the segment where the company operates (Roussy, 2018). These risks can be divided into three groups: risks of changes in market prices, risks of changes in market demand and supply, risks of changes in the life cycle of the markets themselves (Ratas, 2017).

It is impossible to avoid uncertainty and all risks in the enterprise. However, analyzing the state of stocks of certain types of food, grain crops, it is possible to predict, with a certain probability, the price situation on the world agrarian markets and the possible risks from changing market conditions. In this context, the main purpose of this research is to study the origins of the market risks emergence and their impact on the cost of agribusinesses in the new business environment, in connection with which, to solve this problem a new method for assessing them is proposed.

\section{Research methodology}

The research is based on the data from the Ministry of Agrarian Policy and Food of Ukraine (Minagro). In the search for ways to overcome the market risks that exist in agribusiness, the producer, first, should determine the risks that significantly affect the performance of its activities, as well as the tools to minimize this impact. Farmers who annually engage in the production in this area do not normally analyze the impact of certain types of products on the value capitalization of the enterprise and the feasibility of replacing them with more promising ones.

We suggest solving this problem with the help of the ABC-analysis of the agricultural product mix, the "sales as contribution to cost recovery" analysis which will give the company the real opportunity to determine the efficiency of its range and optimize it (Dibb, 2001; Zipf, 1949). Our method should combine the traditional calculation of the company value based on its potential capitalization in the forecast and post-forecast period with the procedure for optimizing the income of the agro-enterprise by the ABC-analysis. Therefore, for the comprehensive assessment of the market risks impact on the agro-enterprise value, we suggest using the following algorithm (Figure 1):

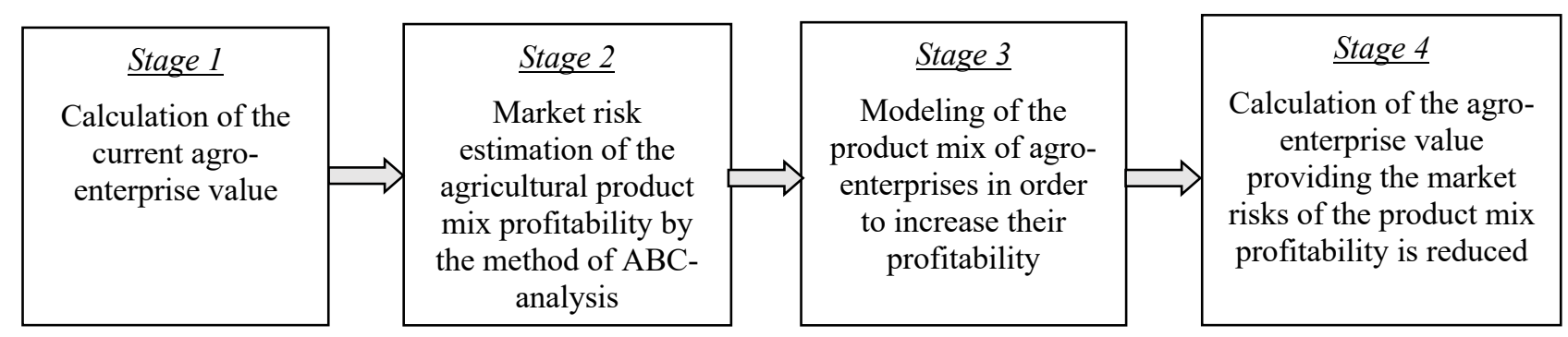

Fig 1. The algorithm of integrated assessment of the market risks impact on the agroenterprise value 
Stage 1: Calculation of the current agro-enterprise value.

To calculate the current agro-enterprise value we propose using the method of direct income capitalization. It is based on the transformation of the net operating income (I) received from the operation of the object under evaluation into value $(\mathrm{V})$ by means of the capitalization factor $(\mathrm{r})$ :

$$
\mathbf{V}=\frac{\mathbf{I}}{\mathbf{r}}
$$

This method measures the current company value and allows us to judge the efficiency of using all the assets in terms of their ability to generate income. The main advantage of this method is the simplicity of calculations. Another advantage is that the method of direct capitalization reflects the market situation immediately. analysis.

Stage 2: Estimation of profitability market risks of the agricultural product mix by the ABC-

To assess the profitability market risks of the agricultural product mix, the ABC-analysis can be used. This type of analysis is based on the Paretto Law, according to which $20 \%$ of the effort gives only $80 \%$ of the result, and the remaining $80 \%$ - only $20 \%$ respectively. That is, for any enterprise A Class product are important, $20 \%$ of which provides $80 \%$ of the total sales income (I). Its sales quantity $(\mathrm{Q})$ should be maximized. At the same time, the company receives $15 \%$ of its income by selling $30 \%$ of B Class products (intermediate products) and $5 \%$ of its revenues by selling $50 \%$ of C Class products (by-products).

The general algorithm of the $\mathrm{ABC}$-analysis is as follows:

1) determine the objects under analysis;

2) determine the parameters by which the analysis of the object will be carried out;

3 ) sort the parameters in the order of decreasing the parameter value;

4) determine the $\mathrm{A}, \mathrm{B}$ and $\mathrm{C}$ groups.

Table 1. The ABC-analysis matrix of the product mix profitability

\begin{tabular}{|l|c|c|c|}
\hline Indicator & Class A & Class B & Class C \\
\hline $\mathrm{Q}, \%$ & 20 & 30 & 50 \\
\hline $\mathrm{I}, \%$ & 80 & 15 & 5 \\
\hline $\begin{array}{l}\text { Zone of market risk of } \\
\text { profitability losses }\end{array}$ & $\begin{array}{l}\text { The zone of low market } \\
\text { risk of profitability losses. }\end{array}$ & $\begin{array}{l}\text { The zone of average market } \\
\text { risk of profitability losses. }\end{array}$ & $\begin{array}{l}\text { The zone of high market } \\
\text { risk of profitability losses. }\end{array}$ \\
\hline Function & $\mathrm{I}_{\mathrm{A}}=\mathrm{P}_{\mathrm{A}} \times \mathrm{Q}_{\mathrm{A}} \rightarrow \max$ & $\mathrm{I}_{\mathrm{B}}=\mathrm{P}_{\mathrm{B}} \times \mathrm{Q}_{\mathrm{B}}$ & $\mathrm{I}_{\mathrm{C}}=\mathrm{P}_{\mathrm{C}} \times \mathrm{Q}_{\mathrm{C}} \rightarrow \mathrm{min}$ \\
\hline
\end{tabular}

Stage 3: Modeling of the agricultural product mix in order to increase its profitability.

This stage involves the definition of the product mix positions that will provide the maximum yield to the agribusiness. Eliminating product mix positions will enable agribusiness to use the released resources to increase profitability.

Stage 4: Calculation of the agro-enterprise value, provided that the market risks of the product mix profitability are reduced.

According to the results of the previous stage, the new value of the agro-enterprise is calculated, provided that the market risks of the product mix profitability are reduced through the refusal of the company to produce non-profitable type of commodities.

\section{Results}

It is obvious that market risk is a multidimensional phenomenon and can directly affect the profitability of an agro-enterprise and its value. To test the proposed method for assessing the impact of market risks on the agribusiness value, we use the data of an assumed " $Z$ " company. This agribusiness specializes in manufacture of eight types of agricultural products:

- corn for grain;

- sunflower; 
- milk;

- pork meat;

- winter wheat;

- meat of cattle;

- spring barley;

- soybeans

The income received by " $Z$ " company from a separate product is different. Therefore, an increase or decrease in its share will change the company value. Figure 2 shows the calculation of the product mix profitability of "Z" company and its value over the past five years.

Table 2. Product mix profitability of " $Z$ " company and its value

\begin{tabular}{|l|c|c|c|c|c|}
\hline \multirow{2}{*}{ Indicator } & \multicolumn{5}{c|}{ Income, thousand EUR } \\
\cline { 2 - 6 } & 2014 & 2015 & 2016 & 2017 & 2018 \\
\hline Corn for grain & 252 & 307 & 506 & 850 & 749 \\
\hline Sunflower & 339 & 227 & 411 & 583 & 438 \\
\hline Milk & 328 & 247 & 363 & 373 & 480 \\
\hline Pork meat & 104 & 118 & 160 & 135 & 115 \\
\hline Winter wheat & 92 & 74 & 89 & 104 & 97 \\
\hline Meat of cattle & 51 & 116 & 58 & 47 & 54 \\
\hline Spring barley & 9 & 3 & 22 & 38 & 32 \\
\hline Soybeans & 19 & 61 & 0 & 0 & 0 \\
\hline Annual income, ths. EUR & 1194 & 1154 & 1610 & 2131 & 1965 \\
\hline Capitalization ratio & 0,16 & 0,16 & 0,16 & 0,16 & 0,16 \\
\hline Value of “Z” company, ths. EUR & 7460 & 7212 & 10060 & 13318 & 12284 \\
\hline
\end{tabular}

From Table 2 it is evident that the value of " $Z$ " company began to increase since the agrocompany refused to grow soybeans. To test our hypothesis, we estimate the market risks of the product mix profitability of "Z" company by ABC-analysis (Table 3 ).

Table 3. ABC-analysis matrix of the product mix profitability of " $Z$ " company

\begin{tabular}{|c|c|c|c|c|c|c|c|c|}
\hline \multirow{2}{*}{ Indicator } & \multicolumn{5}{|c|}{ Income, thousand EUR } & \multirow{2}{*}{$\begin{array}{l}\text { Profitability } \\
\text { over } 5 \text { years, } \\
\text { ths. EUR }\end{array}$} & \multirow{2}{*}{$\begin{array}{c}\text { Income } \\
\text { structure, } \\
\%\end{array}$} & \multirow{2}{*}{$\begin{array}{l}\text { Product } \\
\text { class }\end{array}$} \\
\hline & 2014 & 2015 & 2016 & 2017 & 2018 & & & \\
\hline Corn for grain & 252 & 307 & 506 & 850 & 749 & 2664 & 33,1 & \multirow{3}{*}{$\begin{array}{l}\text { A class } \\
\text { products } \\
(80,1 \%)\end{array}$} \\
\hline Sunflower & 339 & 227 & 411 & 583 & 438 & 1998 & 24,8 & \\
\hline Milk & 328 & 247 & 363 & 373 & 480 & 1791 & 22,2 & \\
\hline Meat of pigs & 104 & 118 & 160 & 135 & 115 & 632 & 7,8 & \multirow{2}{*}{$\begin{array}{c}\text { B class } \\
\text { products } \\
(13,5 \%) \\
\end{array}$} \\
\hline Winter wheat & 92 & 74 & 89 & 104 & 97 & 456 & 5,7 & \\
\hline Meat of cattle & 51 & 116 & 58 & 47 & 54 & 326 & 4,0 & \multirow{3}{*}{$\begin{array}{c}\text { C class } \\
\text { products } \\
(6,3 \%)\end{array}$} \\
\hline Barley is springy & 9 & 3 & 22 & 38 & 32 & 104 & 1,3 & \\
\hline Soy & 19 & 61 & 0 & 0 & 0 & 80 & 1,0 & \\
\hline $\begin{array}{l}\text { Annual income, } \\
\text { thousand EUR }\end{array}$ & 1194 & 1154 & 1610 & 2131 & 1965 & 8054 & 100 & $\mathrm{X}$ \\
\hline
\end{tabular}

According to Table 3, the most important product mix for " $Z$ " company is corn for grain, sunflower and milk. The intermediate products are pork meat and winter wheat. In turn, the rest 
commodity products in the enterprise are not very important positions and bring the lowest income. These are, in particular, meat of cattle, spring barley and soybeans.

In order to reduce the market risk of product mix profitability, " $Z$ " company management needs to increase the product share in the $\mathrm{B}$ class by $1.5 \%$ due to the reduction of commodity positions in $\mathrm{C}$ class. This can be achieved through crop rotation on areas previously occupied by spring barley. It is worth sowing more winter wheat. In 2018, spring barley occupied 150 hectares of land, and winter wheat - 256 hectares. The income from 1 hectare of spring barley is 0.21 thousand Euro / ha. And the income from winter wheat is 0,38 thousand EUR / hectare. In the case of sowing other crops, " $Z$ " company may earn additional revenue in 2019: $(0.38-0.21) \times 150=25.5$ thousand EUR. Using Formula for calculating current value of " $Z$ " agro enterprise, one can calculate the increase of income, which will affect its value, namely:

$$
\mathrm{V}_{2019}=(1965+25.5) / 0.16=12441 \text { thousand EUR }
$$

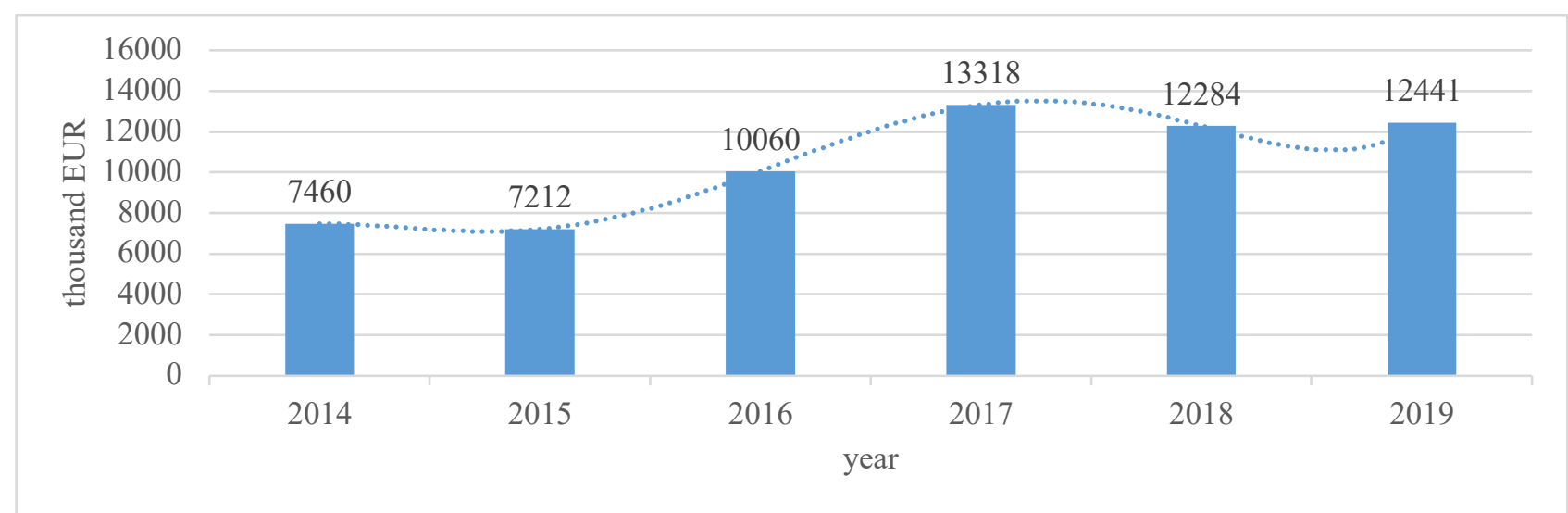

Fig.2. "Z" company value forecast, thousand EUR

Consequently, our hypothesis concerning the influence of market risks of product mix profitability on the agro-enterprise value has been verified. Optimization of the product mix by the $\mathrm{ABC}$-analysis matrix of its profitability $(80 / 15 / 5)$ leads to an increase in the company value.

\section{Conclusions}

According to the results of the study, it can be stated that market risks associated with the product mix profitability have a significant impact on the agro-enterprise value $(\Delta \mathrm{V}=[5-20 \%])$. When properly evaluated, by using economic, mathematical and logistic methods of analysis, company executives can make sound management decisions that will help increase the agribusiness value. The reduction of the market risk level is possible through introducing a system of limits on the use of valuable natural resources and diversification.

Comparison of the actual and optimal income structure received from the sale of a certain agricultural product mix reveals significant reserves to increase the value of agribusinesses.

When conducting a regular $\mathrm{ABC}$-analysis, it is possible to develop your own strategy to transfer low-yielding products from $\mathrm{C}$ class to $\mathrm{B}$ class. This is possible to be implemented due to the improvement of product quality, including the means of rational crop rotation, the revision of pricing policy, etc.

Possible further direction of research is a detailed classification of market risks of agroenterprises and their impact on the company value, taking into account the peculiarities of doing business in different countries. 


\section{Acknowledgements}

The work was carried out with the support of the Ministry of Education and Science of Ukraine within the framework of the research topic "Neo-economics and imperatives of entrepreneurship development" 2016-2020 (state registration number 0116U001555).

\section{References}

Arrow, K. (1971). The Theory of Risk Aversion. - In: Helsinki, Y.J.S., Ed., Aspects of the Theory of Risk Bearing, Reprinted in Essays in the Theory of Risk Bearing, Markham Publ. Co., Chicago. P. 90-109.

Bakchai, T., Mesen, D., Liko, D. and others (1979). Economic risk and methods for measuring it. - Moscow: Economics. P. 133

Boiko, V. (2017). Diversification of business activity in rural areas as a risk minimization tool of economic security // Management Theory and Studies for Rural Business and Infrastructure Development. Vol. 39(1): p. 19-32. Online access: http://mts.asu.lt/mtsrbid/article/view/1023 [09 06 2019]

Bollerslev, T. (1986). Generalised Autoregressive Conditional Heteroskedasticity // Journal of Econometrics. № 31: p. 307-27.

Craft, R., Leake, C. (2002). The Pareto principle in organizational decision making // Management Decision. Vol. 40, №8: p.729-733. Online access: https://doi.org/10.1108/00251740210437699 [09 06 2019]

Dibb, S., Simkin, P., Bradley J. A. (2001). Marketing Planning: A Workbook for Marketing Managers. Thomson Business Press, p. 254.

Gontareva, I. (2011). Influence of timeliness in reproduction processes upon system efficiency of enterprise development // Actual Problems of Economics. Vol. 116 (2): p. 69-76. Online access: http://www.scopus.com/inward/record.url?eid=2-s2.0-84930491411\&partnerID=MN8TOARS [09 06 2019]

Keynes, J. (1936). The General Theory of Employment, Interest and Money. Online access: https:/cas2.umkc.edu/economics/people/facultypages/kregel/courses/econ645/winter2011/generaltheory.pdf [09 06 219]

Knight, F. (1921). Risk, Uncertainty and Profit. Online access: https://papers.ssrn.com/sol3/papers.cfm?abstract_id=1496192 [23 06 2019]

Lakis, A. (2013). Evaluation of influence of the transactions costson farm's economic perfmance // Management Theory And Studies For Rural Business And Infrastructure Development. № 35(1): p. 74-80. Online access: http://mts.asu.lt/mtsrbid/article/view/106/135[09 06 2019]

Sons, p. 334.

Markowitz, H. (1959). Portfolio Selection: Efficient Diversification of Investments. - New York: John Wiley \&

Marshall, A. (1879). The Pure Theory of Foreign Trade: The Pure Theory of Domestic Values. - London: The London School of Economics and Political Science.

Neumann, J., Morgenstern, O. (1944). Theory of Games and Economic Behavior. - Princeton University Press, Princeton. P. 625 p.

Roussy, C., Ridier, A., Chaib, K., Boyet, M. (2018). Marketing contracts and risk management for cereal producers //Agribusiness. №34: p. 616-630. https://doi.org/10.1002/agr.21549 [09 06 2019] ed [28 0519$]$

Senior, N. (1854). Political Economy. 3rd ed. - https://oll.libertyfund.org/titles/senior-political-economy-1850-

Sharp, W. (1964). Capital Asset Prices: A Theory of Market Equilibrium Under Conditions of Risk // The Journal of Finance. № 19(3): p. 425-442. Online access: 10.1111/j.1540-6261.1964.tb02865.x[09 06 2019]

Shoaib, A., Gu-cheng LI, Adnan, N., Amar, R., Raza, U. (2019). Maize production under risk: The simultaneous adoption of off-farm income diversification and agricultural credit to manage risk // Journal of Integrative Agriculture. № 18(2): p.460-470. Online access: https://doi.org/10.1016/S2095-3119(18)61968-9 [09 06 2019] Press, p. 573.

Zipf, G. (1949). Human behavior and the principle of least effort. - Cambridge, (Mass.): Addison-Wesley 